\title{
Seasonal changes in spermatogenesis and testicular steroidogenesis in the male black bear Ursus americanus
}

\author{
T. Tsubota ${ }^{1}$, L. Howell-Skalla ${ }^{1}$, H. Nitta ${ }^{1}$, Y. Osawa ${ }^{3}$, J. I. Mason ${ }^{4}$, \\ P. G. Meiers ${ }^{2}$, R. A. Nelson ${ }^{2}$ and J. M. Bahr ${ }^{1 *}$ \\ ${ }^{1}$ Department of Animal Sciences and ${ }^{2}$ Department of Internal Medicine, University of Illinois, Urbana, \\ IL 61801, USA; ${ }^{3}$ Endocrine Biochemistry Department, Medical Foundation of Buffalo, Buffalo, NY, USA; \\ and ${ }^{4}$ Department Clinical Biochemistry, University of Edinburgh, Royal Infirmary, Edinburgh NHS Trust, \\ Lauriston P1, Edinburgh EH3 9 YW, UK
}

\begin{abstract}
American black bears, Ursus americanus, are seasonal breeders with a mating season in late spring to early summer. The objectives of this study were to determine whether there are seasonal changes in spermatogenesis and immunolocalization of testicular steroidogenic enzymes, and to correlate these changes with peripheral steroid concentrations. Three captive mature bears were maintained in open cages during the summer season and provided with chambers for denning during the winter. Testicular biopsies and blood samples were obtained from anaesthetized bears on 12 March, 15 June, 12 October and 15 January. Steroidogenic enzymes were immunolocalized using polyclonal antisera raised against bovine adrenal cholesterol side-chain cleavage cytochrome P450 (P450scc), human placental $3 \beta$-hydroxysteroid dehydrogenase $(3 \beta \mathrm{HSD})$, porcine testicular $17 \alpha$-hydroxylase cytochrome P450 (P450c17) and human placental aromatase cytochrome P450 (P450arom). Spermatogenesis changed seasonally: spermatogonia and degenerating spermatocytes were observed in October; spermatogonia and primary spermatocytes were present in January; spermatogonia, spermatocytes and round spermatids were present in March; and spermatogonia through spermatozoa were present in June. P450scc and P450c17 were immunolocalized in spermatids and Leydig cells in June, whereas in October these enzymes were present only in Leydig cells. $3 \beta \mathrm{HSD}$ was localized in Leydig cells in June and October with more intense staining in June. Localization of P450arom changed seasonally: no immunostaining in October; positive immunostaining in Sertoli cells in January; more extensive immunostaining in Sertoli cells, peritubular-myoid cells and round spermatids in March; and strong immunostaining in Sertoli cells and round and elongating spermatids in June. Serum testosterone and oestradiol concentrations changed seasonally: testosterone and oestrogen were low in October and January, slightly higher in March, and high in June. The present study demonstrates that in the black bear seasonal changes in spermatogenesis are accompanied by changes in the immunolocalization of testicular steroidogenic enzymes that are correlated with changes in serum testosterone and oestradiol concentrations. The presence of P450arom in Sertoli cells at the beginning of testicular recrudescence suggests that aromatase and oestrogen may play a role in re-initiating spermatogenesis.
\end{abstract}

\section{Introduction}

Mammals in temperate regions exhibit a seasonal cycle in reproduction with spermatogenesis and testicular steroidogenesis limited to a specific time of the year. Seasonal changes in testicular size and morphology and in peripheral testosterone concentrations have been reported in numerous species including California ground squirrels Spermophilus beecheyi (Holekamp and Talamantes, 1991), ferrets Mustela putorius furo

*Correspondence.
(Neal et al., 1977), fallow deer Dama dama (Asher and Peterson, 1991), Cape Mountain zebras Equus zebra zebra (Penzhorn and van der Merwe, 1988) and Hawaiian monk seals Monachus schauinslandi (Atkinson and Gilmartin, 1992). Further information regarding seasonal changes in testicular function is available in an extensive review by Lincoln (1989).

Bears in temperate regions also have a seasonal cycle of reproduction. The black bear, Ursus americanus, is a long day breeder with a mating season extending from May to July (Erickson and Nellor, 1964; Craighead et al., 1969; Ballard et al., 1982). The testes regress in autumn before denning and begin 
to recrudesce during mid- to late denning (Erickson and Nellor, 1964). Active spermatogenesis is observed in the black bear from mid-May until late July and from February to September in the Hokkaido brown bear (Erickson and Nellor, 1964; Tsubota and Kanagawa et al., 1989). The seasonal changes in testes size are paralleled by the seasonal changes in serum testosterone concentrations. Serum testosterone concentrations are lowest in autumn and highest during May-July (McMillen et al., 1976; Palmer et al., 1988; Tsubota and Kanagawa, 1989; Horan et al., 1993). Garshellis and Hellgren (1994) reported an increase in serum testosterone concentrations during late winter (February-March) supporting the idea that testicular function is re-initiated during denning.

These seasonal changes in testicular size and serum testosterone concentrations suggest significant changes in spermatogenesis and testicular steroidogenesis. Tsubota ef al. (1993) described the immunolocalization of steroidogenic enzymes in the testis of the Hokkaido brown bear, but only during the pre-mating season in April. Therefore, the aims of this study were: (1) to characterize seasonal changes in spermatogenesis; (2) to determine the localization of steroidogenic enzymes in the testis during the mating and non-mating season; and (3) to determine whether immunolocalization of testicular steroid enzymes correlates with changes in serum testosterone and oestradiol concentrations.

\section{Materials and Methods}

\section{Animals}

Three sexually mature male black bears maintained at the Carle Foundation Bear Research Facility (Champaign County, IL) were used for this study. The facility is located outdoors and consists of a denning area connected to a large outdoor run where the bears can exercise freely. As a result, the bears experienced annual changes in daylight and temperature. Studies were approved by the Carle Medical Foundation Animal Care and Use Committee. Bears were fed commercial dog chow daily except during the denning period which extended from 13 October, 1992 to 12 March, 1993.

Bears were anaesthetized with $5 \mathrm{mg}^{\text {Telozol }}{ }^{\mathrm{R}} \mathrm{kg}^{-1}$ (Fort Dodge Lab, Fort Dodge, IA) given intramuscularly. Bears were weighed and then blood samples were obtained from the femoral vein. Testicular size was expressed in $\mathrm{mm}^{3}$ and determined by measuring the length $\times$ width $\times$ height of each testis. Serum concentrations of urea and creatinine were determined using the methods of Nelson et al. (1984).

\section{Testicular biopsies}

Testicular samples were obtained under aseptic conditions by needle biopsy. Biopsy samples were collected on 15 January, 12 March, 15 June, and 12 October from each testis of each bear. The scrotal area was prepared aseptically for surgery, a small incision made, the biopsy needle inserted, a sample obtained and the incision sutured. Testicular tissues were immediately fixed in Bouin's solution.

\section{Histology}

Testicular biopsy samples were fixed in Bouin's solution for 3-4 h, dehydrated, embedded in paraplast, and $5 \mu \mathrm{m}$ sections prepared. Sections, five per bear, were then stained with haematoxylin and eosin. Seminiferous tubules, ten per bear, were evaluated histologically using an Olympus photomicroscope with a $\times 40$ objective lens. The movable cursor dot (approximately $0.1 \mu \mathrm{m}$ in diameter) was used for measuring diameter. Jandel Scientific Sigma Scan ${ }^{18}$ Image Analysis software (Jandel Scientific, Corte Madera, CA) and a Numonics Graphics Digitizer (Numonicus Corporation, Montgomeryville, PA) were used for processing measurements. The repeatability of measurements, expressed as a coefficient of variation for ten measurements, was $0.74 \%$ at $10 \mu \mathrm{m}$ and $5.8 \%$ at $0.7 \mu \mathrm{m}$.

\section{Immunocytochemistry}

Paraffin was removed from testicular sections and they were incubated with $10 \%$ normal goat serum to reduce background staining caused by the secondary antibody. The sections were then incubated with primary antibody (1:500 or 1:1000) raised against bovine adrenal cholesterol side-chain cleavage cytochrome 450 (P450scc) (Anakwe and Payne, 1987), human placental $3 \beta$-hydroxysteroid dehydrogenase (3BHSD) (Doody et al., 1990), porcine testicular $17 \alpha$-hydroxylase cytochrome 450 (P450c17) (Hales et al., 1987) and human placental cytochrome 450 (P450arom) (Kitawaki et al., 1989) for immunolocalization of pregnenolone-, progestin-, androgen- and oestrogen-producing cells, respectively. Control sections were treated with normal rabbit serum in place of the primary antibody. Sections were incubated with a secondary antibody conjugated to biotin and then processed with a rabbit ExtraAvidin ${ }^{(i)}$ staining kit (Sigma, St Louis, MO). Immunocytochemistry was performed in triplicate (three sections per testis per bear).

\section{Steroid measurements}

Serum samples were assayed for testosterone and oestrogen by radioimmunoassay as described by Palmer et al. (1988). Recovery of labelled testosterone and oestradiol (1000 c.p.m. per tube) added to serum before extraction was $83.2 \%$ and $84.4 \%$, respectively. The crossreactivity of the antisera were reported by Bahr et al. (1983). The testosterone and oestradiol radioimmunoassays for the black bear were previously validated by column chromatography, parallelism and recovery of unlabelled ligand (Palmer et al., 1988). Sensitivity of the testosterone and oestrogen assays was 8 pg per tube and 2 pg per tube, respectively. Intra-assay and interassay coefficients of variation were $7.7 \%(n=5)$ and $13.3 \%(n=9)$ for testosterone and $5.7 \%(n=6)$ and $11.5 \%(n=9)$ for oestrogen.

\section{Statistical analysis}

Significant differences in body mass and urea:creatinine ratios were calculated using Student's $t$ test. Statistical significance was tested to the $99 \%$ level $(P<0.01)$. Data are expressed as means, with variance expressed as standard deviation of the mean (mean $\pm \mathrm{SD}$ ). 
Table 1. Seasonal changes in body mass, urea:creatinine (U:C) ratios, testicular size and seminiferous tubule diameter in three captive male black bears

\begin{tabular}{|c|c|c|c|c|}
\hline \multirow[b]{2}{*}{ Measurements } & \multicolumn{4}{|c|}{ Season } \\
\hline & October & January & March & June \\
\hline Body mass $(\mathrm{kg})$ & $203 \pm 23^{\prime \prime}$ & $152 \pm 16^{\mathrm{a}}$ & $138 \pm 1 I^{1}$ & $190 \pm 20^{\circ}$ \\
\hline U:C ratio & $20.3 \pm 1.3^{\prime \prime}$ & $6.3 \pm 0.8^{b}$ & $3.4 \pm 1.2^{\mathrm{b}}$ & $15.5 \pm 6.4^{a}$ \\
\hline Testicular size $\left(\mathrm{cm}^{3}\right)$ & $314 \pm 8^{11}$ & $325 \pm 28^{a}$ & $235 \pm 54^{\prime \prime}$ & $364 \pm 38^{\circ}$ \\
\hline Seminiferous tubule diameter $(\mu \mathrm{m})$ & $149 \pm 22^{.1}$ & $127 \pm 13^{\mathrm{a}}$ & $163 \pm 16^{\prime \prime}$ & $199 \pm 14^{3}$ \\
\hline
\end{tabular}

Values are means \pm s.). Body mass, U:C ratios and testicular size are the means of observations from three bears.

".l'Means with different superscripts are significantly different $(P<0.01)$ using Student's $t$ test.
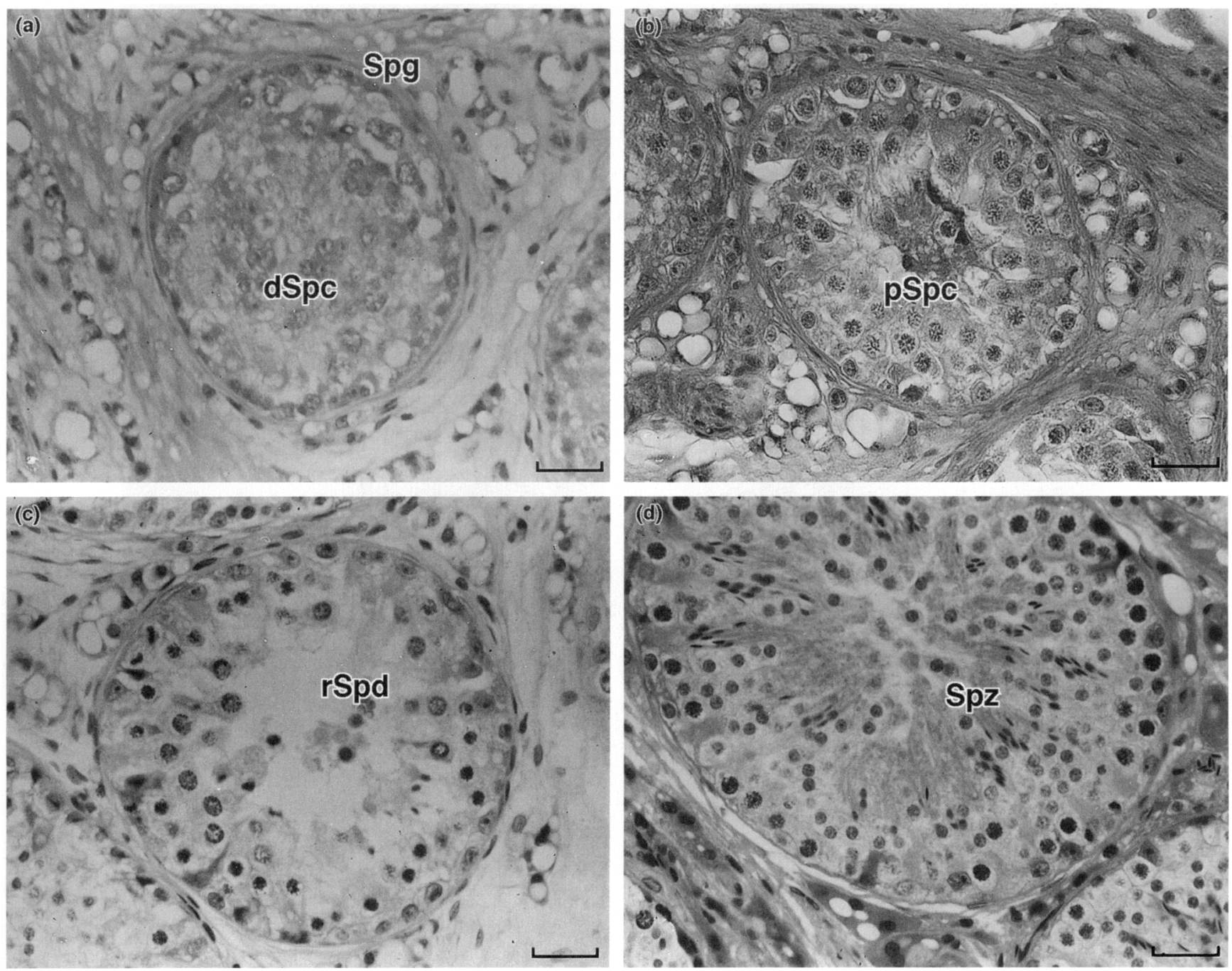

Fig. 1. Seasonal changes in seminiferous epithelium of the black bear testis. (a) In October, spermatogonia (Spg) and degenerating spermatocytes (dSpc) were present in seminiferous tubules. (b) In January, spermatogonia and primary spermatocytes (pSpc) were present. (c) In March, seminiferous tubules contained spermatogonia, spermatocytes and round spermatids (rSpd). (d) In June, the entire spermatogenic population from spermatogonia to spermatozoa (Spz) was observed. Scale bars represent $30 \mu \mathrm{m}$. 

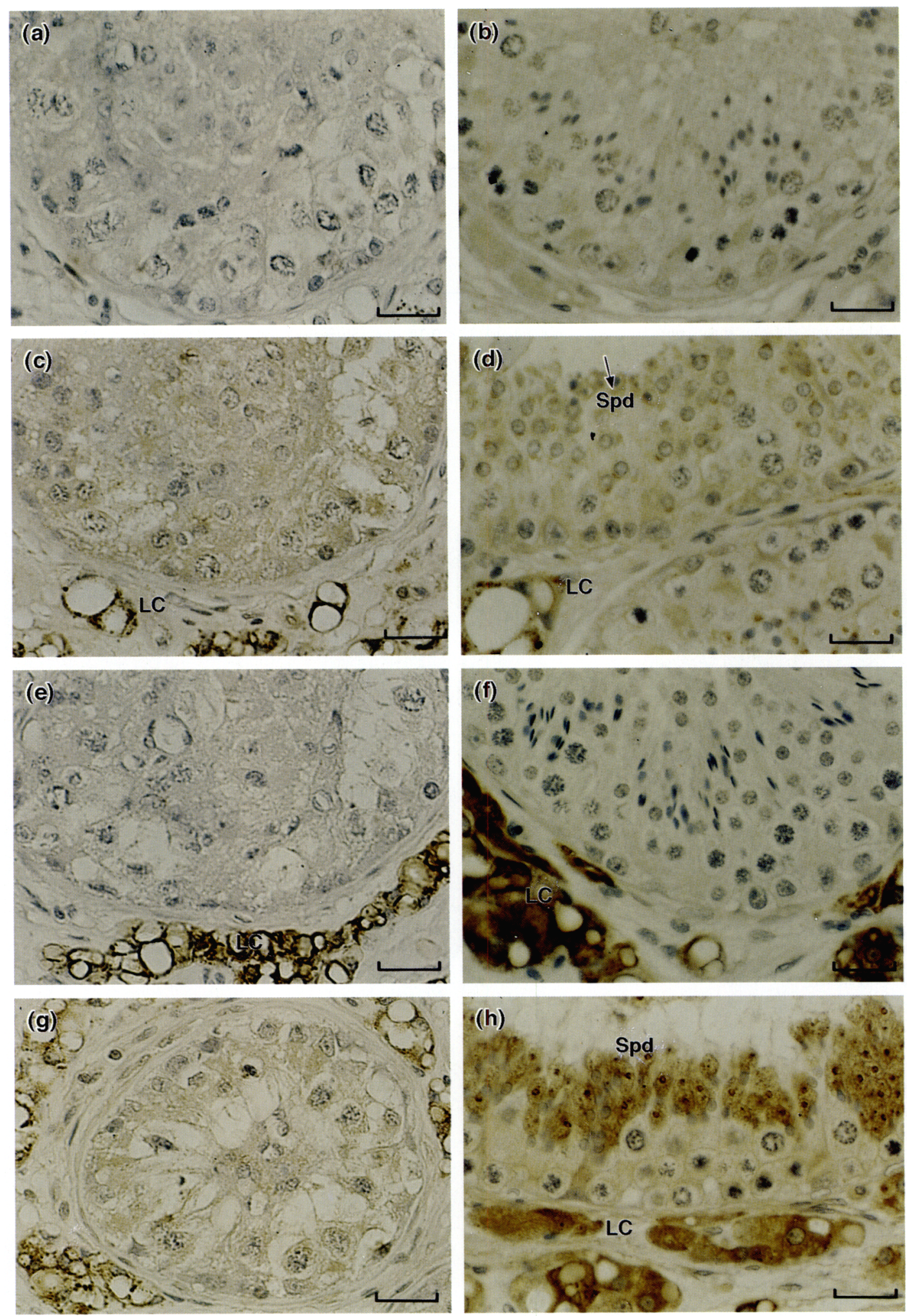

Fig. 2. Immunolocalization of steroidogenic enzymes in the testis of the non-mating (a, $c, e$ and g) (October) and mating ( $b, d, f$ and $h$ ) (June) black bear. ( $a, b)$ Control incubated with normal rabbit serum in place of primary antiserum. (c, d) Immunostaining for cholesterol side-chain cleavage cytochrome P450 (P450scc). Leydig cells (LC) in both October and June were positively immunostained. In June, weak immunostaining was present in spermatids (Spd). (e, f) Immunostaining for $3 \beta$-hydroxysteroid dehydrogenase (3ßHSD). Immunostaining was present in Leydig cells (LC) in both June and October. ( $g$, h) Immunostaining for $17 a$-hydroxylase cytochrome p450 (P450c17). Immunostaining was localized in spermatids (Spd) and Leydig cells (LC) in June and only in Leydig cells in October. All sections were counterstaincd with haematoxylin. Scale bars represent $27 \mu \mathrm{m}$. 

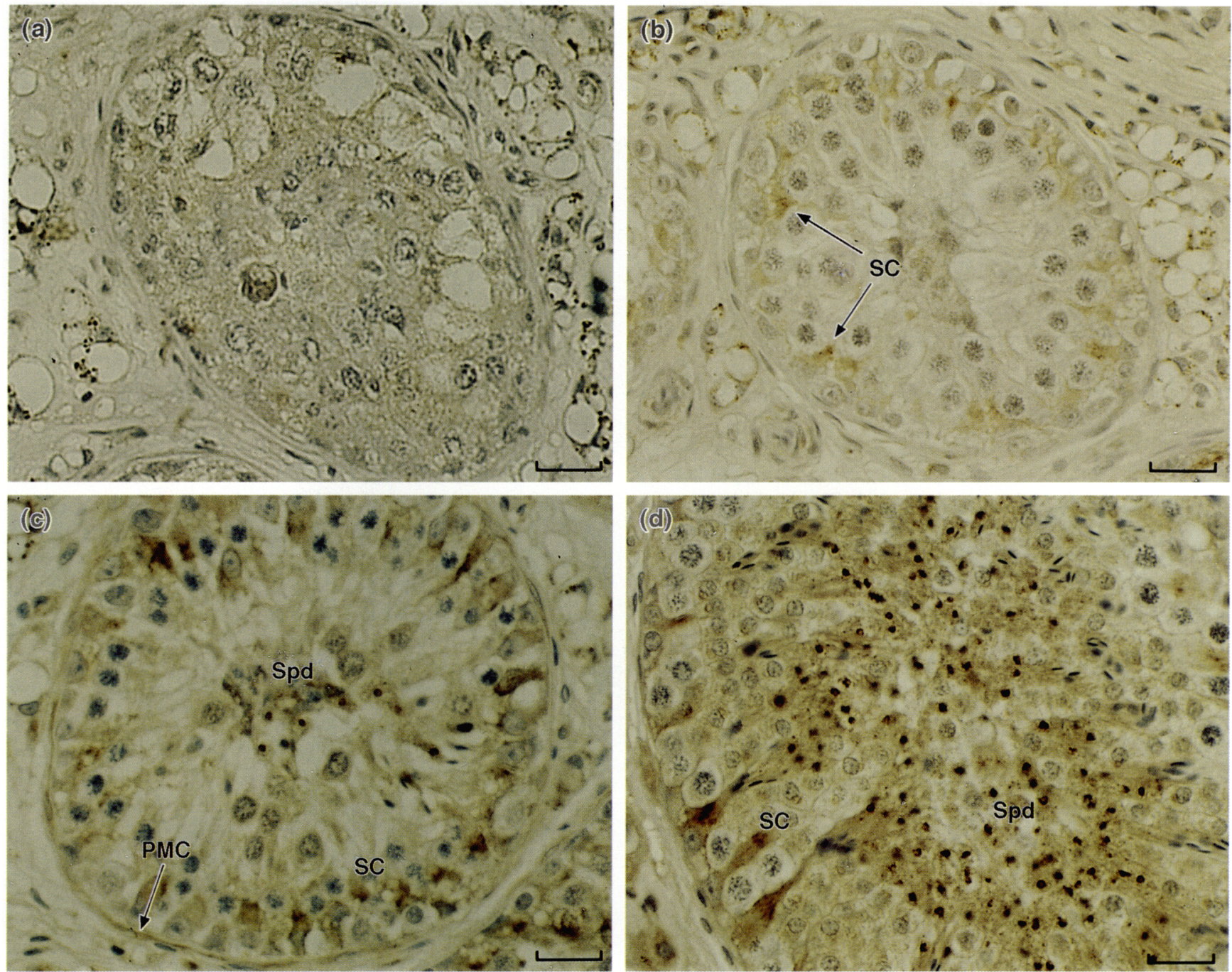

Fig. 3. Seasonal changes in the immunolocalization of aromatase cytochrome p450 (P450arom) in the black bear testis. (a) In October, negligible immunostaining was observed. (b) In January, P450arom was localized in Sertoli cells (SC). (c) In March, positive immunostaining was localized in Sertoli cells (SC), peritubular-myoid cells (PMC), and a few spermatids (Spd). (d) In June, strong immunostaining was observed in Sertoli cells (SC) and round and elongating spermatids (Spd). All sections were counterstained with haematoxylin. Scale bars represent $25 \mu \mathrm{m}$.

\section{Results}

\section{Body mass and urea:creatinine ratio}

Body masses (mean $\mathrm{kg} \pm \mathrm{SD}$ ) of the three active bears in June $(190 \pm 20)$ and October $(203 \pm 23)$ were significantly greater than those of the three denning bears in January (152 \pm 16$)$ and March (138 \pm 11$)(P<0.01)$ (see Table 1). Indicative of metabolic denning, the serum urea:creatinine ratio (mean U:C \pm SD) decreased significantly during denning from values of $15.5 \pm 0.4$ and $20.3 \pm 1.3$ in June and October to values of $6.3 \pm 0.8$ and $3.4 \pm 1.2$ in January and March $(P<0.01$ ) (see Table 1).

\section{Testicular size, seminiferous tubule diameter and spermatogenesis}

Testicular size and seminiferous tubule diameter changed seasonally with the largest values observed during the mating season in June (testicular size: $x=364 \mathrm{~mm}^{3}$; seminiferous tubule diameter: $x=199 \mu \mathrm{m}$ ) and the lowest values during the non-mating season (testicular size in March: $x=235 \mathrm{~mm}^{3}$; seminiferous tubule diameter in January: $x=127 \mu \mathrm{m}$ ) (see Table 1). The extent of germ cell development depended upon season (Fig. 1). In October, only spermatogonia and degenerating spermatocytes were present (Fig. 1a), whereas spermatogonia and spermatocytes were present in January (Fig. 1b). In March, spermatogonia, spermatocytes and round spermatids were present (Fig. Ic) and the entire spermatogenic cell population from spermatogonia to spermatozoa was present in June (Fig. Id).

\section{Immunocytochemistry}

P450scc, 3BHSD and P450c17 were localized by immunocytochemistry in testicular biopsies obtained in bears during the mating season in June and the non-mating season in October, whereas P450arom was localized in testicular biopsies 


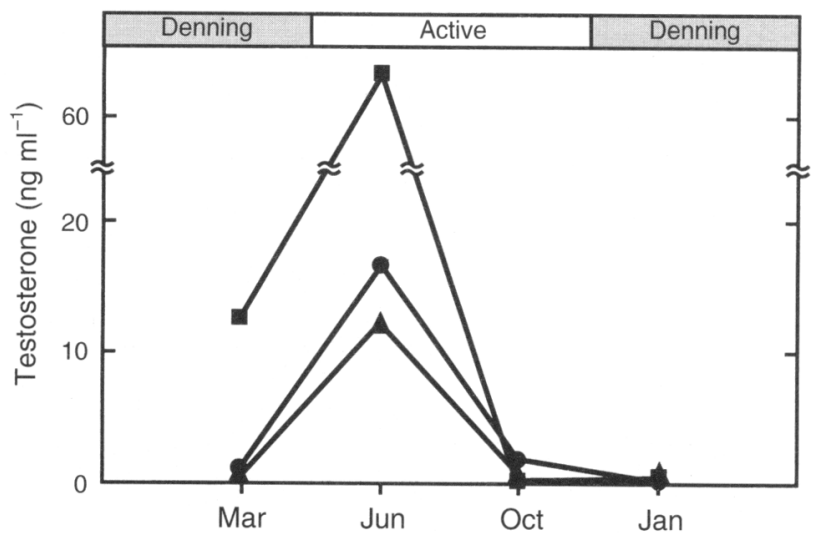

Fig. 4. Seasonal changes in serum concentrations of testosterone in three male black bears.

obtained in January, March, June and October. No specific staining was present in control sections when normal rabbit serum was substituted for the primary antibody (Fig. 2a,b). Seasonal changes in the immunolocalization of P450scc (Fig. 2c,d) and P450c17 (Fig. 2g,h) were very similar: these enzymes were present in both Leydig cells and spermatids in June during the mating season but only in Leydig cells in October during the non-mating season. Leydig cells stained positively for $3 \beta \mathrm{HSD}$ in October and even more intensely in June (Fig. 2e,f). Localization of P450arom changed markedly with season. P450arom immunostaining was absent in the regressed testis in October (Fig. 3a) but present in Sertoli cells during the beginning of recrudescence in January (Fig. 3b). As recrudescence continued in March, there was more extensive immunostaining in Sertoli cells, peritubular-myoid cells and round spermatids (Fig. 3c). The most extensive immunostaining was present in Sertoli cells and round and elongating spermatids (Fig. 3d) in June during the mating season. Observations were similar among all three bears.

\section{Steroid hormone measurements}

Serum testosterone concentrations showed seasonal changes (Fig. 4). Testosterone concentrations were lowest in October (range for three bears: $0.1-2.0 \mathrm{ng} \mathrm{ml}^{-1}$ ) and January $(0.4-$ $\left.0.6 \mathrm{ng} \mathrm{ml}^{-1}\right)$, slightly higher in March $\left(0.6-12.4 \mathrm{ng} \mathrm{ml}^{-1}\right)$ and high in June (12.4-63.2 $\mathrm{ng} \mathrm{ml}^{-1}$ ). Seasonal changes in serum oestradiol concentrations were similar to those observed in serum testosterone concentrations (Fig. 5). Oestradiol concentrations were low in October (range for three bears: 19-25 pg $\left.\mathrm{ml}^{-1}\right)$ and increased slightly in January $\left(25-27 \mathrm{pg} \mathrm{ml}^{-1}\right.$ ). Oestradiol concentrations were higher in March $(20-44 \mathrm{pg}$ $\left.\mathrm{ml}^{-1}\right)$ and further increased in June $\left(44-70 \mathrm{pg} \mathrm{ml}^{-1}\right)$.

\section{Discussion}

This is the first study to investigate the relationship between seasonal changes in spermatogenesis, testicular steroidogenic enzymes, and serum steroid profiles in black bears. The onset of spermatogenic activity was observed in January, the mid- to late denning period, as demonstrated by the reorganization

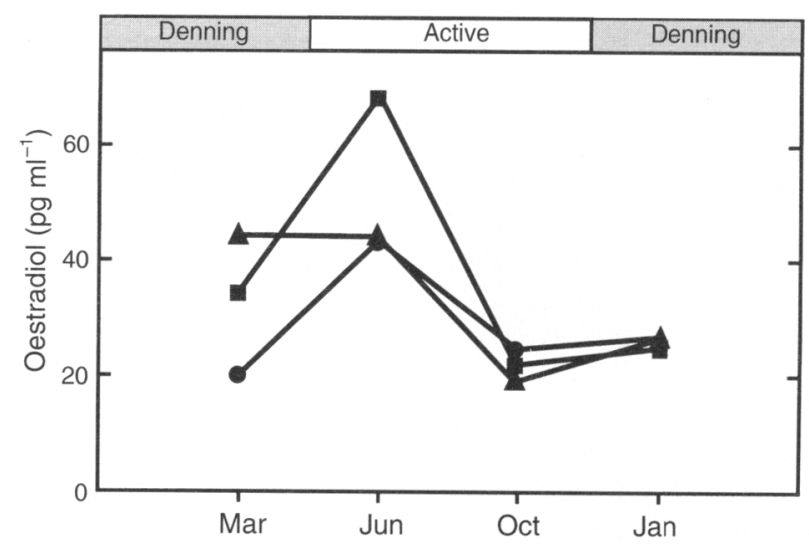

Fig. 5. Seasonal changes in serum concentrations of oestradiol in three male black bears.

of the seminiferous tubules and the presence of primary spermatocytes. Recrudescence continued through March and was complete in June. The observation of the onset of spermatogenic activity in January is the earliest documentation of testicular recrudescence in the black bear. Erickson and Nellor (1964) reported enlarged seminiferous tubules in one bear obtained in April. Tsubota and Kanagawa (1989) observed active spermatogenesis in the brown bear in February.

Immunolocalization and staining intensity of the steroidogenic enzymes P450scc, 33HSD, P450c17 and P450arom in the testis of the black bear changed seasonally. P450scc, 3ßHSD and P450c17 were localized in Leydig cells in both June and October; however, the staining of $3 \beta \mathrm{HSD}$ and P450c17 in Leydig cells was more intense during the mating season than the non-mating season. These findings are similar to those observed in other species that exhibit seasonal reproduction in that the intensity of staining for testicular steroidogenic enzymes was most intense when the testes were fully active (Lincoln, 1989). The immunocytochemical data reported here are also supported by in vitro studies of steroid synthesis in which tissue obtained from the regressed testis of the grey squirrel was less capable of synthesizing androgens from labelled C21 steroid precursors than from tissue obtained during peak reproductive activity (Pudney and Lacy, 1977). In addition, our immunocytochemical data appear to correlate with the seasonal changes in peripheral testosterone concentrations and reproductive activity in black bears, an observation similar to other species that exhibit seasonal reproduction.

Immunolocalization of P450arom changed markedly with season. The most interesting observation was the appearance of aromatase in Sertoli cells in January suggesting a role for oestrogen in re-initiating spermatogenesis during gonadal recrudescence. In the immature rat, oestrogen is produced by Sertoli cells and it may be important in controlling prepubertal sexual maturation (Dorrington and Armstrong, 1975; Dorrington et al., 1978; Rommerts et al., 1982; Tsai-Morris et al., 1985; Rosselli and Skinner, 1992). The observation that changes in the seminiferous epithelium during sexual maturation paralleled those observed during recrudescence has allowed us to hypothesize that oestrogen may be important for the initiation of spermatogenesis in the seasonally breeding bear. 
In addition, the immunocytochemical data reported here suggest that germ cells are sites of steroidogenesis. Germ cells stained positively for $\mathrm{P} 450 \mathrm{scc}, \mathrm{P} 450 \mathrm{c} 17$ and $\mathrm{P} 450$ arom during active spermatogenesis in June. This observation extends previous studies in which active P450arom was found in developing spermatids and spermatozoa in mice, rats, and roosters (Nitta et al., 1993; Kwon et al., 1995; Janulis et al., 1996). It has been suggested that oestrogen has a role in sperm maturation in the epididymis.

Finally, this is the first report of seasonal changes in serum oestradiol concentrations in male black bears. Seasonal changes in serum oestradiol were similar to changes observed in serum testosterone. Serum oestradiol concentrations decreased in autumn, increased slightly in January, were further increased in March, and were high in June. Serum concentrations of oestradiol appeared to parallel the presence of $\mathrm{P} 450$ aromatase in the testis as demonstrated by immunocytochemical staining. It is not known whether oestrogen has a role in regulating the hypothalamic-pituitary-testicular axis in bears.

In summary, a positive relationship was demonstrated between seasonal changes in spermatogenesis, testicular steroidogenic enzymes, and serum steroid profiles in the black bear, a long day breeder. Future studies will be directed to understanding the role of gonadotrophins and prolactin in testicular recrudescence.

This work was supported in part by grants from Carle Foundation Hospital. The authors are grateful to A. Payne of Stanford University for her kind donation of the anti-bovine adrenal P450scc and anti-porcine testicular P450c17 antibodies.

\section{References}

Anakwe $\mathrm{OO}$ and Payne AH (1987) Noncoordinate regulation of de novo synthesis of cytochrome P450 cholesterol side-chain cleavage and cytochrome P450 17 $\alpha$-hydroxylase/c17-20 lyase in mouse Leydig cell cultures: relation to steroid production Molecular Endocrinology 1 596-603

Asher GW and Peterson AJ (1991) Pattern of LH and testosterone secretion of adult male fallow deer (Dama dama) during the transition into the breeding season Journal of Reproduction and Fertility 91 649-654

Atkinson S and Gilmartin WG (1992) Seasonal testosterone pattern in Hawaiian monk seals (Monachus schauinslandi) Journal of Reproduction and Fertility 96 35--39

Bahr JM, Wang S-C, Huang MY and Calvo FO (1983) Steroid concentrations in isolated theca and granulosa layers of preovulatory follicles during the ovulatory cycle of the domestic hen Biology of Reproduction 29 326-334

Ballard W, Miller SD and Sparaker TH (1982) Home range, daily movements, and reproductive biology of the brown bear in south central Alaska Canadian Field-Naturalist 96 I-5

Craighead JJ, Hornocker MG and Craighead FC (1969) Reproductive biology of young female grizzly bears Journal of Reproduction and Fertility Supplement 6 $447-475$

Doody KM, Carr BR, Rainy WE, Byrd W, Murry BA, Strickler RC, Thomas JI and Mason JI (1990) 3ß-hydroxysteroid dehydrogenase/isomerase in the fetal zone and neocortex of the human fetal adrenal gland Endocrinology 126 2487-2492

Dorrington JH and Armstrong DT (1975) Follicle-stimulating hormone stimulates estradiol-17 $\beta$ synthesis in cultured Sertoli cells Proceedings of the National Academy of Sciences USA 72 2677-2681

Dorrington JH, Fritz IB and Armstrong DT (1978) Control of testicular estrogen synthesis Biology of Reproduction 18 55-64
Erickson AW and Nellor JE (1964) Breeding biology of the black bear. In The Black Bear in Michigan pp 5-45 Eds AW Erickson, J Nellor and GA Petrides. Michigan State University Agricultural Experimental Station Research Bulletin 4, East Lansing, Michigan

Garshellis D and Hellgren EC (1994) Variation in reproductive biology of male black bears Journal of Mammology 75 175-188

Hales DB, Sha $\mathbf{L}$ and Payne AH (1987) Testosterone inhibits cAMP-induced de novo synthesis of Leydig cell cytochrome $\mathrm{P} 45017 \alpha$ by an androgen receptor-mediated mechanism Journal of Biological Chemistry 26211 20011206

Holekamp KE and Talamentes F (1991) Seasonal variation in circulating testosterone and oestrogens of wild-caught California ground squirrels (Spermophilus beecheyi) Journal of Reproduction and Fertility 93 415-425

Horan KT, Nelson RA, Palmer SS and Bahr JM (1993) Seasonal response of the pituitary and testes to gonadotropin-releasing hormone in the black bear (Ursus americanus) Comparative Biochemistry and Physiology 106A $175-182$

Janulis L, Hess RA, Bunick D, Nitta H, Janssen S, Osawa Y and Bahr JM (1996) Mouse epididymal sperm contain active $\mathrm{P} 450$ aromatase which decreases as sperm traverse the epididymis Journal of Andrology 17 111-117

Kwon S, Hess RA, Bunick D, Nitta H, Janulis L, Osawa Y and Bahr JM (1995) Rooster testicular germ cells and epididymal sperm contain $\mathrm{P} 450$ aromatase Biology of Reproduction 53 1259-1264

Kitawaki J, Yoshida N and Osawa Y (1989) An enzyme-linked immunosorbent assay for quantitation of aromatase cytochrome P450 Endocrinology 124 1417-1423

Lincoln GA (1989) Seasonal aspects in testicular physiology in seasonal mammals. In The Testis pp 229-385 Eds H Burger and D de Kretser. Raven Press, New York

McMillen JM, Seal US, Rogers L and Erickson AW (1976) Annual testosterone rhythm in the black bear (Ursus americanus) Biology of Reproduction 15 163-167

Neal J, Murphy BP, Moger WH and Oiphant LW (1977) Reproduction in the male ferret: gonadal activity during the annual cycle; recrudescence and maturation Biology of Reproduction 17 380-385

Nelson RA, Beck TDI and Steiger DL (1984) Ratio of serum urea to serum creatinine in wild black bears Science $226841-842$

Nitta H, Bunick D, Hess RA, Janulis L, Newton SC, Millette CF, Osawa Y, Shitzutu Y, Toda K and Bahr JM (I993) Germ cells of the mouse testis express P450 aromatase Endocrinology 132 1396-1401

Palmer SS, Nelson RA, Ramsay MA, Stirling I and Bahr JM (1988) Annual changes in serum sex steroids in male and female black (Ursus americanus) and polar (Ursus maritimus) bears Biology of Reproduction 38 1044-1050

Penzhorn BL and van der Merwe NJ (1988) Testis size and onset of spermatogenesis in cape mountain zebras (Equus zebra zebra) Journal of Reproduction and Ferfility 83 371-375

Pudney J and Lacy D (1977) Correlation between ultrastructure and biochemical changes in the testis of the American grey squirrel, Sciurus carolinensis, during the reproductive cycle Journal of Reproduction and Fertility 49 5-16

Rommerts FFG, de Jong FH, Brinkmann AO and van der Molen HJ (1982) Development and cellular localization of rat testicular aromatase activity Journal of Reproduction and Fertility 65 281-288

Rosselli M and Skinner MK (1992) Developmental regulation of Sertoli cell aromatase activity and plasminogen activator production by hormones, retinoids, and the testicular paracrine factor, PModS Biology of Reproduction 46 586-594

Smith TR (1986) Activity and behavior of denned black bears in the lower Mississippi river valley International Conference of Bear Research and Management 6 137-143

Tsai-Morris C-H, Aquilana DR and Dufan ML (1985) Cellular localization of rat testicular aromatase activity during development Endocrinology 116 38-46

Tsubota T and Kanagawa H (1989) Annual changes in serum testosterone levels and spermatogenesis in the Hokkaido brown bear, Ursus arctos yesoensis. Journal of Mammology Society Japan 14 11-17

Tsubota T, Nitta H, Osawa Y, Mason JI, Kita I, Tiba T and Bahr JM (1993) Immunolocalization of steroidogenic enzymes, P450scc, 3ß-HSD, P450c17, and P450arom in the Hokkaido brown bear (Ursus arctos yesoensis) testis General and Comparative Endocrinology 92 439-444 